\title{
The Reconciliation of the World Through the Blood of Christ's Cross as the Completion of the Work of Creation (Col 1:15-20)
}

\author{
JANUSZ KRĘCIDŁO \\ Cardinal Stefan Wyszyński University in Warsaw \\ oldicerkj@gmail.com, ORCID: 0000-0002-0913-5513
}

\begin{abstract}
The article contains a detailed exegesis of the Christological hymn in Col 1:15-20, highlighting the links between the theology of creation and kerygmatic theology. The first strophe (1:15-18a) emphasizes the author's intention to show the function of Christ in the creation of the world, whereas the second one (1:18b-20) exposes the fact that Christ's passion, death and resurrection were key moments in the history of the world, comparable only to the work of its creation. It is shown that both events are closely related in the hymn because reconciling the world to God in the blood of Christ is meant to be the completion of the work of creation, resulting in restoring a harmonious relationship between God and man.
\end{abstract}

Keywords: Col 1:15-20, Christology, reconciliation, creation theology, kerygmatic theology

This article aims at exegetically exploring the Christological hymn in Col 1:15-20. In order to achieve this, the function of Col 1:15-20 in the argumentative structure of the entire letter will firstly be examined, followed by a brief explanation of the most important literary aspects of the pericope. Finally, a detailed and comprehensive exegetical analysis of the hymn in terms of Christ's function as the One who, by God's will and through his work of reconciliation, completes the work of creation, will be conducted.

\section{The Place of Col 1:15-20 in the Argumentative Structure of the Letter}

The problem of the function of $\mathrm{Col} 1: 15-20$ in the pragmatic argumentation of the entire letter is inextricably linked with its author's purpose concerning the composition. ${ }^{1}$ Traditionally, scholars assume that the letter consists of two main parts:

1 The current state of research (in 2010) on Colossians is briefly presented in Gupta, "New Commentaries on Colossians," 7-14. 
dogmatic (chapters 1-2) and moral (chapters 3-4). ${ }^{2}$ The author's pragmatic goal was to counter certain harmful tendencies in the community of the Church in Colossae, generally referred to as the "Colossian heresy." It seems that the Letter to the Colossians could have been a kind of catechism presenting a coherent vision of the Christian faith to the faithful of pagan origin in an epistolary form. ${ }^{4}$ Writing Colossians, in which one can see elements of deliberative, demonstrative and juridical rhetoric, the author intended to show the beauty and sublimity of the Christian faith. However, attempts to designate the main thesis in Col (using both rhetorical and epistolary analysis methods) around which its entire content would be integrated has not brought satisfactory results.

In general, exegetes divide Colossians into six units ${ }^{5}$ :

1. Epistolary introduction (1:1-2).

2. Initiation of the path of faith (1:3-23).

3. Paul's participation in the mystery of Christ and his concern for the faith of the addressees (1:24-2:5).

4. Life in Christ and threats to faith (2:6-3:4).

5. Following Christ with a Christian lifestyle (3:5-4:6).

6. Concluding instructions and greetings (4:7-18).

The hymn in Col 1:15-20 is, therefore, an element of the structural unit that occurs immediately after the epistolary introduction in which Paul ${ }^{6}$ thanks God for the faith of the addressees and asks for it being strengthened in Christ. The purpose of this Christological hymn is to sensitize Colossian readers (who were largely pagans converted to the Christian faith) to the absolute primacy and central role of Christ in their lives. Paul argues that Christ, who is revealed in the Church, has universal and indivisible authority over all creation, which God decided to reconcile to himself through his saving mission.

2 See Lindemann, Der Kolosserbrief, 14.

3 This issue is competently reported by Bartosz Adamczewski (List, 141-142). See also Beale, Colossians, 12-15; McKnight, S., "Introduction"; White, Der Brief des Paulus, 35-45. Mark S. Medley ("Subversive Song," 421-435) argues that "the Colossian hymn draws upon the political ideology and imagery of the Roman Empire in the form of a counter-discourse, as was Jewish resistance poetry" (ibidem, 421). He sees Col 1:15-20 as a Christological song of protest against the legitimation of the Roman imperial power. The pragmatic intention of the hymn is to convince that "Christ is the one true Lord of all things, including the Roman Empire. Cosmic, universal lordship and redemption are the key notes of this song of protest and promise" (ibidem, 434-435). Similarly, Wright, "Disarming the Rulers and Authorities," 446-457.

4 See Adamczewski, List, 143. For a slightly different and more detailed proposal of the outline and argument of Colossians see Beale, Colossians, 17-21.

5 Cf. Adamczewski, List, 144.

6 In this article, we do not go into the question of Paul's authorship. As we can read in the letter, it was written by Paul and Timothy. Scholars have confronted this position treating Paul's authorship as disputed and classifying the letter as Deutero-Pauline. 


\section{Literary Peculiarities of Col 1:15-20 and Its Structure}

Col 1:15-20 is an example of hymnic poetry. ${ }^{7}$ Exegetes sometimes postulate to look for its Sitz im Leben in the early Christian baptismal liturgy or to treat it not as a canticle, but as a Christological confession of faith. ${ }^{8}$ It seems, however, that the genre matrix for Col 1:15-20 should rather be sought in the Old Testament hymns (e.g., psalms) and blessings. ${ }^{9}$

In terms of rhetorical features, Col 1:15-20 can be interpreted as an encomium, that is, a song of praise in honour of some extraordinary figure. ${ }^{10}$ In the Hellenistic-Roman literature of that time, we can find numerous works written in prose and poetry, celebrating the uniqueness of outstanding figures by exposing the extraordinary circumstances of their births in famous places, as well as by emphasizing the extraordinary qualities of their characters and deeds. These works were written in honour of rulers and people of particular merit for the community in the political, religious and other spheres of public life. ${ }^{11}$ In the Hellenistic-Roman culture, the rhetorical encomium was also a way of praising gods by exposing their features, such as greatness, power, majesty, domination, care and kindness to their faithful believers.

An important place in the contemporary discussion on Col 1:15-20 is occupied by the problem of the literary origin of these verses. There is an almost universal consensus that this Christological hymn was not a product of Paul's literary-theological genius or of the Pauline school, ${ }^{12}$ but a creative reworking of an earlier work that could have gone back to pre-Christian times. ${ }^{13}$ As the proposals are very divergent, it is worth mentioning the most important of them. ${ }^{14}$ Some exegetes claim that the origins of this hymn (especially vv. 15-18a) should be sought in pre-Christian, Judaic circles because in the current form of this work there are similarities to

7 On this topic see Barth - Blanke, Colossians, 227-245. Hymnic characteristics in Col 1:15-20 aptly describes Steven R. Tracy (Living, 64-70).

8 These issues are discussed, for example, by David E. Garland (Colossians, 82-85).

9 See Adamczewski, List, 189.

10 See Tracy, Living, 81, who argues that the hymn aims to "centre upon the defence of the gospel, particularly the person and work of Christ, in the face of the Colossian opponents." See also Trainor, "The Cosmic Christology," 67: "the hymn seeks to recognise the social reality of the Colossian Christians. It celebrates the nature and function of Jesus in cosmic and universal terms, and imaginatively expands on the place of the Church, Jesus' 'body, over which he is its head."

11 See also Barth - Blanke, Colossians, 236-241.

12 See the whole discussion and bibliography in Tracy, Living, 70-79; White, Der Brief des Paulus, 16-28.

13 Various scholars still believe that the hymn was originally written by the author of Colossians acknowledging that he may have utilized the traditional material while composing the hymn. See e.g., Moule, The Epistles, 60-62; Balchin, "Colossians 1:15-20," 67-94; Helyer, "Colossians 1:15-20," 167-179; McKnight, "Introduction."

14 Apart from these suggestions, attention is drawn to the similarity between the ideas present in Col 1:15-20 and the Stoic, Platonic and Hermetic thought. However, no textual proposals are given that would be a model for Col 1:15-20. 
the Old Testament hymns praising God's Wisdom (e.g., Wis 7:25-8:4; Prov 8:22-31; Sir 24:3-12) ${ }^{15}$ Others see the original material as a Gnostic hymn about the Redeemer ${ }^{16}$ or about some divine-human being descending to earth. Still others believe that Paul adapted, completed and incorporated some early Christian hymn to Christ into Colossians. ${ }^{17}$ Since the authors of these hypotheses cannot indicate any reliable source of such an original hymn, which then could have been re-edited and included in the epistle, it is more probable that it was created in the Pauline school, ${ }^{18}$ which creatively elaborated ideas from the wisdom tradition of the Old Testament ${ }^{19}$ and from various currents of Judaism and Hellenism of that time. The aim of this creative work would be the theological exposition of the idea of Christ's dominion over the entire cosmos. ${ }^{20}$

The exegetes are not unanimous on the internal structure of the hymn in Col 1:15-20. ${ }^{21}$ The vast majority of them propose to divide this pericope into two strophes. ${ }^{22}$ However, there are also scholars who distinguish three, four and even five strophes in this fairly short passage. ${ }^{23}$

15 See MacDonald, Colossians, 66-67.

16 First suggested by Ernst Käsemann ("A Primitive Christian Baptismal Liturgy," 158-159).

17 See Balchin, "Colossians 1:15-20," 65-94. See also Schweizer, "Colossians 1:15-20," 98-100.

18 John Behr ("Colossians 1:13-20," 247-248), following Barth's commentary (Barth - Blanke, Colossians, 235), believes that the hymn was written by the author of the letter (Paul or another person).

19 The Old Testament allusions and echoes in the entire Letter to the Colossians are extensively presented by Gordon D. Fee ("Old Testament Intertextuality in Colossians," 201-221), Christopher A. Beetham (Echoes of Scripture), Jerry L. Sumney ("Writing "in the Image" of Scripture," 185-229), Gregory K. Beale (“The Old Testament in Colossians," 261-274). Paul Foster ("Echoes without Resonance," 96-111; Colossians, 60) argues that there is no conscious use of the Old Testament within the letter.

20 John A. Dunne ("The Regal Status of Christ," 3-18) rightly emphasizes that a part of the conceptual background of the hymn is provided by regal motifs. The idea of Christ's lordship is one of the main emphasis of the whole Colossians. See among others the works by Andreas Dettwiler ("Démystification celeste," 330), Nahjib Ibrahim (Gesù Cristo Signore dell'universo), Ingrid Maisch (Der Brief; Clark, Completing Christ's Afflictions, 81). Some commentators dissent from this common opinion arguing that the idea is scarcely present in the letter. See Standhartinger, Studien zur Entstehungsgeschichte, 205-219; Dübbers, Christologie und Existenz, and recently on the basis on lexical and syntactical data, Feník - Lapko, "The Reign of Christ in Colossians," 495-516.

21 John Behr ("Colossians 1:13-20," 148-149) argues that the hymn starts in Col 1:13 and has a chiastic structure with the central thought (5-E): "and He is the Head of the body, the Church" in 1:18a.

22 See details in Taylor - Reumann, Ephesians, 125-126; Trainor, "The Cosmic Christology," 61-64. See also Bruce ("The 'Christ Hymn' of Colossians 1:15-20," 99-100, 104-106) who notes a transitional link in 1:17-18a.

23 A summary of these hypotheses can be found in Tracy, Living, 79-80. See also Adamczewski, List, 192. 


\section{The First Strophe (1:15-18a)}

The hymn in Col 1:15-20 begins with the relative pronoun ös (nominative, masculine, singular), indicating Christ the Son of God, in whom both the author and the addressees have redemption - the forgiveness of sins, in the context of verses 13-14

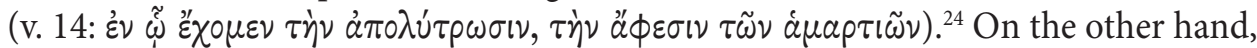
in the following context, 1:21-23, the author makes the Colossians aware that they,

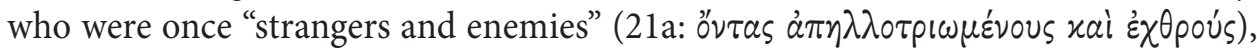
were reconciled thanks to Christ's death. This context determines the main line of meaning for the interpretation of individual expressions contained in the hymn, the pragmatic intention of which aims to show the addressees the role of Christ in the work of reconciling man to God.

The hymn first makes the addressees aware of Christ's relationship with God

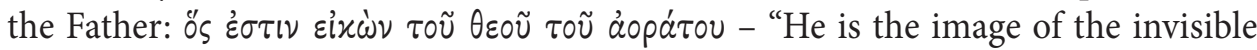
God." Calling God áópatos "invisible" echoes both the OT theological concepts as well as the philosophical and cosmological ideas of the Hellenistic world. ${ }^{25}$ The invisibility of God in the Old Testament is presumed wherever there are angels representing him, communicating his will to men (e.g., Gen 16:7-12; 22:11-12; Exod 3:2-6; 14:19-20). This should also be noticed in the legal regulations prohibiting the making of God's images (Exod 20:4-6; Deut 5:8-10) and indirectly in the prohibition of uttering his name. In the broadly understood Hellenistic culture of that time, the concept of a deity's invisibility results from the Platonic division of reality into a world experienced by senses and a world of ideas available only to mental cognition. Philo of Alexandria probably refers to this division in his theological concept of the invisible God. ${ }^{26}$

The idea of the invisibility of God necessarily implies the question: "How then can we know the invisible God when he is unavailable to sensual knowledge?" The Hellenistic world of the New Testament times answered this question by referring to the concept of the image $\varepsilon i x \omega \dot{ }$, which is indicated in Col 1:15, when Christ is called the image of the invisible God. ${ }^{27}$ The Greek noun $\varepsilon^{i x} \dot{\omega} \omega$ can be translated into English as "image, representation, reflection, likeness." ${ }^{28}$ Plato calls the world an "image" of God (Timaios, 92c) and the Sun an "image" of the idea of good (Respubli$c a, 6.509$ a). Hellenistic thought was also no stranger to the idea of man as the image of God. ${ }^{29}$

24 This context is emphasized by F.F. Bruce (The Epistles, ad loc.) and John P. Heil (Colossians, 64). See also Metcalf, "The Atonement," 284.

25 This idea appears explicitly three more times in the New Testament: Rom 1:20; 1 Tim 1:17 and Heb 11:27.

26 See Dunn, The Epistle, 87.

27 The background of the concept is discussed by David H. Johnson ("The Image," 9-15).

28 Louw - Nida, Greek-English Lexicons, 1923.

29 Bauer - Danker, A Greek-English Lexicon, 2260. 


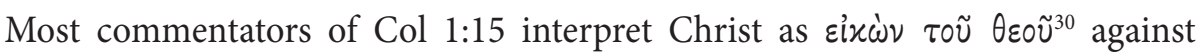
the background of the Old Testament. ${ }^{31}$ They essentially follow two directions. Some believe that the author refers to the idea - so prominent in Paul's theology - that every man, like Adam, is an image of God (see 1 Cor 11:7). By analogy, Christ as the New Adam is in a special way the image of God (the lexical correspondence between Col 1:15 and 2 Cor 4:4). ${ }^{32}$ Others interpret the concept of Christ as the image of the invisible God against the background of the Old Testament wisdom literature, ${ }^{33}$ which reflects the ideas of Hellenistic Judaism. In Jewish thought, developed especially by Philo of Alexandria ${ }^{34}$ but also present in Wis 7:26, the invisible God makes himself visible through wisdom. The idea of wisdom as the image of the invisible God allowed the theologians of the Hellenistic Judaism to place a bridge between the unknowable world of the invisible God and the visible created world (including humanity). The wisdom of God, often personified in the Logos, was seen in Hellenistic Judaism both as the agent of God's image and the image itself. ${ }^{35}$ According to Jewish sages, the idea of wisdom as the image of God found its embodiment in the Torah. This is especially evident in the Book of Sirach (24:23) and the Book of Baruch (3:36-4:1). Similarly, for the author of Colossians, God's wisdom, which is the image of God, is identified with Christ as his most perfect manifestation. ${ }^{36}$ The emphasis is more on the revelatory than ontological aspect of the Father-Son relationship. ${ }^{37}$ Taking into account the foregoing context (1:14), the author of the hymn explains in 1:15 that the salvific and redemptive mission of Christ, the termination of which was the death on the cross, is the continuation and completion of God's work of creation. Presenting Christ as the image of God perfectly fits into Jewish monotheism because it does not make him a distinctive subject, independent of the Father - the Creator is also the Redeemer. ${ }^{38}$ The interpretation of Christ as the image of God in the light of

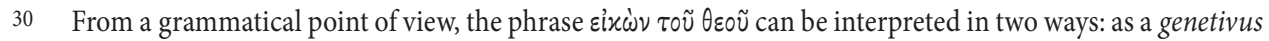
possesoris - the emphasis would be on Christ's belonging to God, and as a genetivus obiectivus - Christ as the image of God reflects him in himself. The second possibility seems to correspond more closely with the theological intention of the author of Colossians. The same conclusion is deduced by Margaret Y. MacDonald (Colossians, 58). See also Trainor, "The Cosmic Christology," 64-65.

31 See Barth - Blanke, Colossians, 247-249; Hughes, Philippians, ad loc. See also McConnell, "Colossians," 404; Macaskill, "Union(s) with Christ," 93-99.

32 Such a solution is strongly supported, for example, by Adamczewski (List, 195) (excluding the OT wisdom context). Christopher Northcott ("King of Kings' in other Words," 205) argues that in Col 1:15 Christ "is presented as the legitimate ruler of the world, potentially in deliberate contrast to the world rulers of that day: the emperors of Rome, who were thus viewed by the merit of their special relationship with their gods."

33 See also Bruce, The Epistles, ad loc.; Moo, The Letter to the Colossians, ad loc. Contrarily Dunne ("The Regal Status of Christ," 9) who states that "this specific idea of image has no parallel in Wisdom tradition." Instead, he sees an allusion to Gen 1:26-28. See e.g., Legum allegoriae 1.43; De confusione linguarum 97.147; De fuga et invention 101; De somnis 1.239. See Dunn, The Epistle, 88.

Dunn, The Epistle, 89.

See Martin, Colossians, 57.

Similarly Thurston, Reading Colossians, 22-23. 
the OT wisdom seems to be theologically broader and more expressive in our context. However, the concept of Christ as the New Adam should not be excluded but treated as complementary.

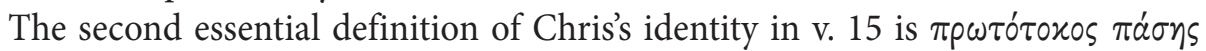
$x \tau i \sigma \varepsilon \omega \varsigma$ - "the firstborn of all creation." ${ }^{39}$ The idea of being firstborn finds an important place in the Old Testament. ${ }^{40}$ The fact of being born as the first male child in a family resulted in the special privilege of inheriting. It seems that in our context the author does not generally refer to this Old Testament background (or more broadly, the cultural background), but the expression "the firstborn of all creation" should be interpreted as a second phrase specifying the identity of Christ. In the wisdom literature of the Old Testament, God's Wisdom was understood as created before everything (Prov 8:22-25; Sir 1:4), accompanying God from the beginning (Wis 9:9) and sharing the throne with God (Wis 9:4). Philo of Alexandria calls wisdom "the firstborn son." 41 In the Jewish sapiential tradition, the "firstborness" of personified Wisdom does not primarily mean being created as God's first work, but the emphasis is on its priority status. ${ }^{42}$ Referring these contents to Christ as "the firstborn of all creation," it should be assumed that this term is not primarily about making the addressees aware of Christ's temporal priority in relation to the whole of creation, but about emphasizing his absolute supremacy over everything that exists in the world. ${ }^{43}$

This interpretation is confirmed further in verse 16, where the author develops the idea of the primacy of Christ as the One who transcends the created world, being the One by whom everything was brought into existence: the Creator ${ }^{44}$ The subordinate conjunction $0 " \tau \iota$ (because, that) at the beginning of verse 16 determines the content to be interpreted as explaining why Christ is the firstborn of all creation. The main reason is above all the fact that "in him all things were created" - $\dot{\varepsilon} \nu$ a $\tau \tau \tilde{\omega}$

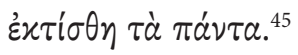

The very sophisticated structure of verse 16 should be noted. ${ }^{46}$ To begin with, both the first and the last line create an inclusion framing the interior lines. In addition,

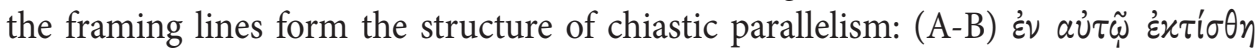

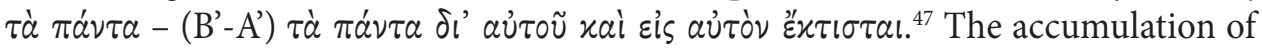
prepositional statements that define Christ's function in the work of creation is also

\footnotetext{
39 On the functioning of this term in Corpus Paulinum, see Barth - Blanke, Colossians, 245-247.

40 For additional information, see Bruce, The Epistles, ad loc. See also Dunne, "The Regal Status of Christ," 13.

41 See De ebrietate 30-31; Quaestiones in Genesis 4.97.

42 See Bauer - Danker, A Greek-English Lexicon, 726.

43 Eduard Lohse (Colossians, 48-49) puts it as follows: "The point is not a temporal advantage but rather the superiority which is due to him as the agent of creation who is before all creation. As the first-born he stands over creation as Lord." Similarly, Thurston, Reading Colossians, 23.

44 See Hughes, Philippians, ad loc.

45 More Garland, Colossians, 88-89.

46 More details in Heil, Colossians, 65-68.

47 This parallelism is also noticed by MacDonald (Colossians, 60).
} 
striking. The author makes readers aware that all visible and invisible, earthly and ce-

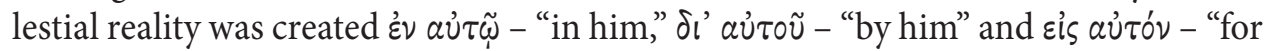
him." Such a condensation of prepositional phrases with an adverbial meaning was the usual way of expressing God's sovereignty over the created world in the Hellenistic-Roman world of that time. It is worth paying attention to several close parallels to

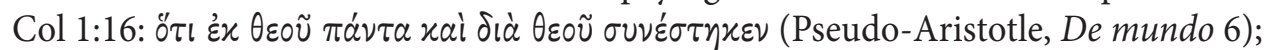

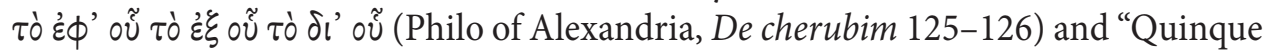
ergo causae sunt, ut Plato dicit: id ex quo, id a quo, id in quo, id ad quod, id propter quod" (Seneca, Epistulae 65.8). Moreover, such terms are quite commonly used in the letters of Paul the Apostle as they are characteristic of numerous doxologies found in the Corpus Paulinum. Suffice it to quote Rom 11:36: "For from him, and through him, and for him are all things. Glory to him forever. Amen." ${ }^{48}$

As noted above, the author's argument in this verse tends to convince the reader of the absolute primacy of Christ in all creation: "in him all was created" ( $\dot{\varepsilon} \nu \alpha \dot{v} \tau \tilde{\omega}$

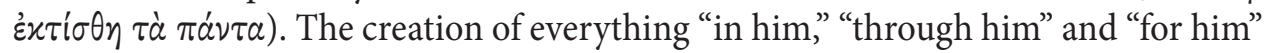
makes him the firstborn ( $\pi \rho \omega \tau$ tó $\tau$ xos in v. 15) of all creation. Two things are particularly noteworthy here. First, the verbs in v. 16 expressing the creative act ( $\dot{\varepsilon} x \tau i \sigma \theta \eta$ and $\varepsilon^{\prime} \chi \tau(\sigma \tau \alpha \iota)$ are in the passive voice. Therefore, here we are dealing with a passivum divinum - it is God the Father who is the Creator, and Christ is the Mediator and the Instrument through whom, in whom and for whom the creative act was made by God. This language becomes clearer when we apply it to the Old Testament theme of God's personified Wisdom accompanying him in creating the world (see above). Jesus the Messiah is shown in Col 1:16 as the embodiment of God's Wisdom. In the context of the following verses of the hymn (vv. 18 and 20), it should be noted that this creative act includes Jesus' death on the cross and his resurrection as well. ${ }^{49}$ Secondly, the use of the two verbal forms for the act of creation is significant. In the first instance ( $\left.\dot{\varepsilon} x \tau^{\prime} \sigma \theta \eta\right)$, the verb takes the form of an aorist indicative, the aspect of which principally indicates a one-time action performed at an undefined time in the past. In the second clause, the author uses the form of perfect tense ( $\left.\varepsilon^{\prime} \chi \tau i \sigma \tau \alpha l\right)$, the aspect of which indicates that God's creative activity is still ongoing or at least its

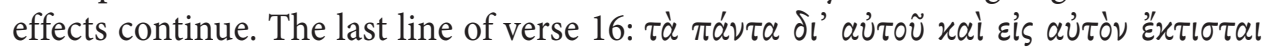
could, therefore, be translated as "all things were created through him and in him and are being still created."

Numerous commentaries focus on establishing the meaning of the four heavenly and earthly beings, which were created in Christ, by Christ and for Christ,

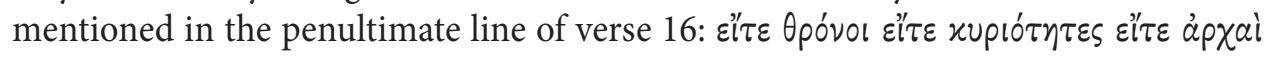

\footnotetext{
48 See also 1 Cor 8:6.

49 Similarly, Aletti, Saint Paul Épitre aux Colossiens, 102-103; Dunn, The Epistle, 91. See also Wellum, "Jesus as Lord and Son," 39.
} 


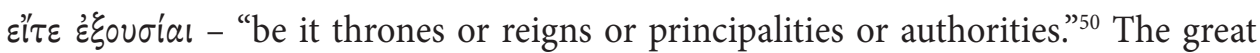
majority of scholars regard them as various heavenly spiritual powers, the identity of which is best explained against the background of intertextual references to biblical and other Jewish literature. "Thrones" should probably be placed highest in this hierarchy of heaven. A good background for a better understanding of this theme may be Dan 7:9; Rev 4:4; Testament of Levi 3.8 and Apocalypse of Elijah 1.10-11. The second place in the hierarchy of these heavenly powers are taken by "dominions" (Eph 1:20-21; 1 Enoch 61.10 and 2 Enoch 20.1). Parallel references to the lower hierarchies of "rulers" and "authorities" can be found a little further in Col 2:10.15, and also, for example, in 1 Cor 15:24 and Eph 1:21; 3:10; 6:12. Some exegetes postulate that the meanings of these four subjects should not only be limited to the angelic powers but also to the visible powers of this world. ${ }^{51}$ The poetic character of the hymn in Col 1:15-20 and above all, the author's statement that it is about Christ's dominion over everything in heaven and on earth, over what is visible and invisible, strongly support this type of interpretation.

The coordinate conjunction $x a$, initiating verse 17 , indicates that the following content will be a continuation of the argument that began in verse 16 with the conjunction ö $\tau$, supporting the thesis about the primacy of Christ over all creation made at the beginning of the hymn in verse 15 . In turn, v. 17 is an addition to the argumentation about the priority of Christ because of the creation of everything through him, in him and for him. A consequence of Christ's primacy in the order of all creation is

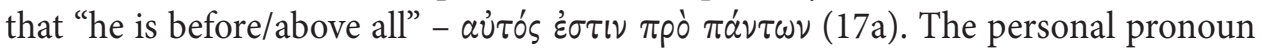
aúós at the beginning of this statement has an emphatic value. It is to designate the idea "he and no one else." ${ }^{52}$ It is followed by the preposition $\pi \rho$ ', which usually has temporal connotations in Greek. ${ }^{53}$ This preposition is syntactically associated with the adjective $\pi \dot{\alpha} \nu \tau \omega \nu$, which should be related to the two occurrences of $\pi \dot{\alpha} \nu \tau \alpha$ with the article $\tau \dot{\alpha}$ in v. 16, and with $\tau \dot{\alpha} \pi \dot{\alpha} \nu \tau \alpha$ in v. $17 \mathrm{~b}$ as well as with $\pi \tilde{\alpha} \sigma \iota \nu$ in v. 18. The adjective $\pi \dot{\alpha} \nu \tau \alpha$ in the form of a neuter plural with the article means everything that is in the universe. Therefore, the occurrence of $\pi \dot{\alpha} \nu \tau \omega \nu$ in v. 17a should also be assigned a neuter gender although grammatically, the masculine gender and feminine gender are also acceptable. So, the thematic emphasis of the hymn focuses on accentuating the absolute temporal priority of Christ over all created beings. ${ }^{54}$ The author of the hymn fits here - as in the preceding context - in the Old Testament

50 See e.g., Lightfoot, Saint Paul's Epistles, 151-152; Bammel, "Versuch," 88-95; Dunn, The Epistle, 92; Adamczewski, List, 201.

51 Such a postulate is put forward by Clinton E. Arnold (The Colossian Syncretism, 251-255) and after him Hugolin Langkammer (Wprowadzenie do Ksiag Nowego Testamentu, 40) and Adamczewski (List, 201).

52 Cf. MacDonald, Colossians, 60.

53 For further discussion, see Moule, The Epistles, 66-67.

54 This interpretation of $\pi \rho \dot{o} \pi \dot{\alpha} v \tau \omega \nu$ in 1:17a is proposed by Ernst Lohmeyer (Die Briefe, 168), C.F.S. Moule (The Epistles, 66-67), Jean-Noël Aletti (Saint Paul Épître aux Colossiens, 103). 
wisdom tradition, ascribing to Christ the same prerogatives of eternity that the sages attributed to God's Wisdom (see e.g., Sir 1:4 or Prov 8:22-31). Without denying this level of meaning, the expression $\pi \rho \dot{o} \pi \dot{\alpha} \nu \tau \omega \nu$ should rather be interpreted complementarily ${ }^{55}$ as indicating the supremacy of Christ in relation to the whole of creation, ${ }^{56}$ as such semantics is suggested by both the previous and the subsequent context.

In the following context (1:17b) the idea that in Christ everything in the uni-

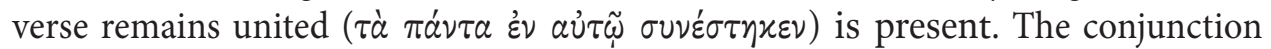
xai opening this statement introduces the idea that is complementary and parallel

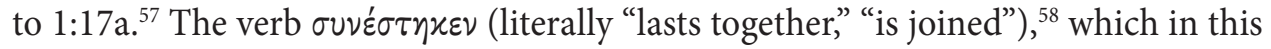
sentence performs the function of a predicate, acts in the grammatical form of perfectum, the aspect of which indicates the current state resulting from a past activity. It is about exposing the truth that now in Christ everything, that is, the whole universe, remains together - it is dependent on him as the principle of its existence. Undoubtedly, the preexistence of Christ the Son of God in relation to everything that exists in the universe is presumed here, but the emphasis is definitely on the present state. ${ }^{59}$ The idea of the world being held together by God's action - and thus its internal cohesiveness and orderliness - resonates with the Hellenistic philosophy of that time, ${ }^{60}$ especially with the Platonic and Stoic thought (see e.g. Plato, Respublica 7; Pseudo-Aristotle, De Mundo 6,2; Philo of Alexandria: De vita Mosis 2,133; De fuga 112; and Quaestiones in Exodum 2,118). ${ }^{61}$ As in the preceding context, also verse 17 reflects a cosmological model of the universe, which was part of Platonic and Stoic ${ }^{62}$ philosophical thought. According to this model, the universe is constantly kept in existence and remains connected thanks to God's Logos. This rational Logos, according to philosophers, provides the world with order ${ }^{63}$ and rules over all changes taking place in the cosmos. Moreover, this philosophical-theological concept is present in Wis 1:6-7; 7:22-8:1, where these prerogatives of keeping the universe coherent and in order are attributed to God's personal Wisdom. ${ }^{64}$ This is another clue for embedding the Christological hymn in the wisdom tradition of the Old Testament as the closest ideological matrix.

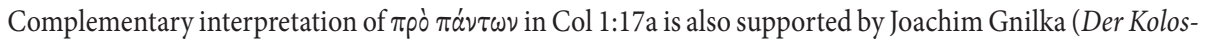
serbrief, 66), Dunn (The Epistle, 93), MacDonald (Colossians, 61).

56 Analogous non-temporal use of the preposition $\pi$ pó is attested also, for example, in Jas 5:12 and 1 Pet 4:8.

57 Similarly Adamczewski, List, 202.

58 This term is comprehensively discussed by C. John Collins (“Colossians 1,17," 64-87).

59 This is also evidenced by the occurrence of the verb દ̇ $\sigma \tau \imath$ in 1:17a in the present tense (parallelism).

60 See Collins, "Colossians 1,17," 69-77.

61 See on this topic Talbert, Ephesians 189.

62 The stoic influence is emphasized by Victoria Balabanski (“The Holy Spirit," 180-182).

63 This thought is also expressed in the New Testament, in Heb 1:3.

64 For further discussion of this problem, see Dunn, The Epistle, 93-94. Collins (“Colossians 1,17," 65-67) gives other possible passages from the Hebrew Bible that can be a background of this verb (e.g., Ps 33:9; 119:90; 148:6; Isa 48:13). 


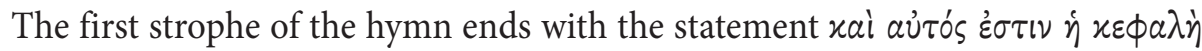
$\tau \circ \tilde{u} \sigma \omega^{\prime} \mu \alpha \tau o \varsigma \tau \tilde{\eta} \varsigma \dot{\varepsilon} x \chi \lambda \eta \sigma^{\prime} a \varsigma$ - "and he is the head of the body of the church" (v. 18a). This poetic line is parallel to the above-analysed verse $17 \mathrm{a}$ and is the last element of the reasoning why Christ is the image of God and the firstborn of all creation. The expression xai auं ós, which initiates the statement, has, like in v. 17a, an emphatic value $^{65}$ and is intended to stimulate the reader and/or listener to reflect on the unique status of Christ. The conjunction xai takes the meaning of "also" in the context of listing the qualities of Christ, and therefore, this expression can be interpreted as " $\mathrm{He}$ also, and no one else."

Christ is called "the head of the body of the church" - $\dot{\eta} x \varepsilon \phi a \lambda \dot{\eta} \tau 0 \tilde{u} \sigma \omega \dot{\omega} \mu \alpha \tau 0 \varsigma$ $\tau \tilde{\eta} \varsigma \dot{\varepsilon} \times x \lambda \eta \sigma^{\prime} \alpha \varsigma$. It is quite an enigmatic statement in which the genitive $\tau \tilde{\eta} \varsigma \dot{\varepsilon} \times x \lambda \eta \sigma^{\prime} \alpha \varsigma_{S}$ slightly disturbs the rhythm of the hymn, hence some authors claim that this noun was added at the stage of literary-theological adaptation of an earlier version of the hymn. ${ }^{66}$

The key concept is "the head" - $\chi \varepsilon \phi \alpha \lambda \eta^{\prime}$, which defines Christ. ${ }^{67}$ The presence of

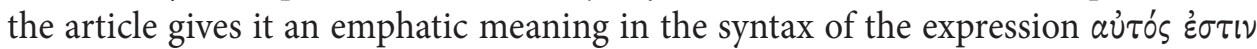
$\dot{\eta} x \varepsilon \phi a \lambda \eta^{\prime}$ - "He is this head." ${ }^{68}$ Thus verse 18a is used in the strophe 1:15-18a to summarize the qualities attributed to Christ in the previous statements regarding his supremacy in the entire created universe. The metaphor of Christ as the head should be interpreted in the light of two occurrences of this noun in the close context of Col 1:18. The first one is in Col 2:10, where Christ is called "the head of all

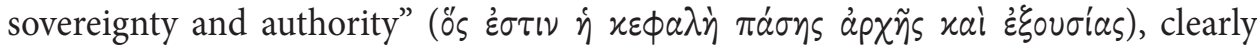
assuming a semantic shade associated with his power and reign. ${ }^{69}$ And in the next instance of $x \varepsilon \phi a \lambda \eta^{\prime}$ in Col 2:19, Christ is seen as the source of the existence and growth of the body. It seems that neither of these two shades should be excluded in Col $1: 18$. The context of the preceding verses in the first strophe of the hymn (1:15-17) evidently leads the reader to see Christ both as the head, i.e. the source and purpose of every creature's existence, and the One who rules over all creation.

However, Christ's function as head in Col 1:18a no longer refers to his supremacy over all creation; the extent of this supremacy is determined by the expression $\tau 0 \tilde{u}$

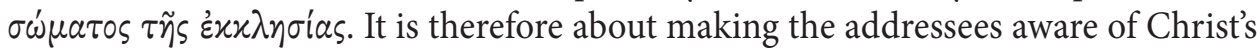
supremacy as head in relation to the "body of the church." ${ }^{70}$ How should this be interpreted? In Hellenistic philosophy, there are assertions that the world is the body of

\footnotetext{
65 See MacDonald, Colossians, 61.

66 See Dunn, The Epistle, 94. An opposite opinion in Feuillet, Le Christ, 217-228; Kehl, Der Christushymnus, $41-45$.

67 See, too, Garland, Colossians, 90-91.

68 Cf. Adamczewski, List, 203-204.

69 Cf. Heil, Colossians, 70-71. See also Dunne, "The Regal Status of Christ," 14; Scharlemann, "The Scope," 296-298.

70 See Moo, The Letter, ad loc.
} 
the head, which is the deity. ${ }^{71}$ This thought appeared in Plato's Timaios (28B) as well as in the Orphic texts, which showed Zeus as the head of the body of all creation. ${ }^{72}$ Philo of Alexandria, on the other hand, writes of the Logos as the head of the whole body ( $\sigma \tilde{\omega} \mu \alpha$ as in Col 1:18a) of the universe (Quaestiones in Exodum 2.68).

In Col 1:18a, the noun $\sigma \tilde{\omega} \mu \alpha$ does not denote the universe, but its semantic range is clarified by the noun $\tau \tilde{\eta} s \dot{\varepsilon} \times x \lambda \eta \sigma$ ias that function in apposition to it. The point in Col 1:18a is then to show Christ as the source and goal of the Church and his authority over her. There is also the question of how the author of the hymn understands the church. Against the background of other appearances of the noun $\dot{\varepsilon} x x \lambda \eta \sigma^{\prime} \alpha$ in the New Testament, we can propose two possible interpretations. It can mean a gathering of people who believe in Christ, i.e. people gathering in his name in the houses and cities of the empire (e.g., in Colossae). This is the meaning of the noun 'ंx $x \lambda \eta \sigma^{\prime} a$, for example, in Rom 16:1.4.5.16; 1 Cor $1: 2 ; 4: 17$ or in Col 4:15-16. Its special case is the plural expression "the church(s) of God" (see, e.g., 1 Cor 1:2; 11:16.22; 15:9; 1 Thess 2:14). If we assumed this meaning in 1:18a, we should speak of Christ's relationship with a specific community of the local church, and it would be the relationship of Christ with believers belonging to this particular community. The second nuance of the meaning of the noun $\dot{\varepsilon} x \times \lambda \eta \sigma^{\prime} \alpha$ in the New Testament, which can be found, for example, in 1 Cor 12:28, results from the etymology of this word in classical Greek, where it meant "calling" and "gathering." It was used in the Septuagint (along with $\sigma u v a \gamma \omega \gamma \eta$ ) as the equivalent of the Hebrew noun qāhāl, which designated the "calling" and "gathering" of God's people, called by Yahweh to glorify him. ${ }^{73}$ Following this line of interpretation, $\dot{\varepsilon} x x \lambda \eta \sigma^{\prime} \alpha$ used in Col 1:18a should not be understood as a concrete community of the local church, but as the universal Church - the whole New People of God. It seems that the interpreter of the hymn in Col 1:15-20 is not faced with the choice of the first or second nuance of the meaning of $\dot{\varepsilon} x \chi \lambda \eta \sigma^{\prime} \alpha$. Undoubtedly, the context of the entire hymn suggests the understanding of Christ as the source and goal of the whole universal Church and his authority over her. On the other hand, the addressees of the letter understood this universal reign of Christ in a very concrete way - in relation to their local community. ${ }^{74}$

\footnotetext{
71 Numerous examples are provided by Dale B. Martin (The Corinthian Body, 15-34).

72 See also Martin, Ephesians, 108.

73 For further discussion, see Dunn, The Epistle, 96; Adamczewski, List, 205.

74 Similarly, Dunn, The Epistle, 96.
} 


\section{The Second Strophe (1:18b-20)}

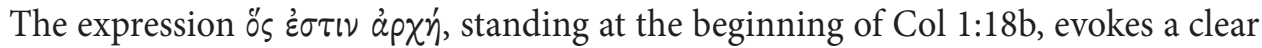

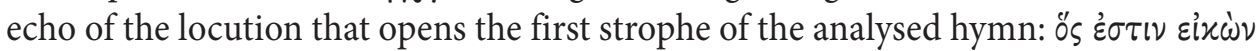
$\tau \circ \tilde{u} \theta \varepsilon \circ \tilde{u}(1: 15) .{ }^{75}$ At the same time, it is a literary opening of the second strophe of the hymn. While the theme of the first strophe focuses on presenting Christ as the source, aim and ruler of the entire created universe, the second part of the hymn stresses the salvific effects of the renewal of mankind through what happened in the phenomenon of the Son of God abiding in the world, especially in his act of reconciliation of the world to God through his passion, death and resurrection. In a poetic way, the author of the hymn divides the history of the world into two main stages. The first one - presented in the first strophe - began with the creation of the world and ended with the incarnation of Christ. As shown above, Christ, as the Firstborn of all creation, participated in the creation of the world and constantly reigns over it. The second stage in the history of the created world, continuing the first one in an essentially new and complementary way, is the period of God's reign in the world through the work of reconciling it to God in Christ's passion, death and resurrection. The second strophe of the hymn should be interpreted along this main semantic line.

In the first line of the second strophe, Christ is referred to as ápxýn. It is a term whose meaning should be read against the background of its use in Judaism of those days. ${ }^{76}$ It is noteworthy that the term ápxý was used to describe God's Wisdom as a person, which should not surprise the reader in view of her several other attributes ascribed to Christ in the first verse - as noted above. ${ }^{77}$ In Prov 8:22, Wisdom is called "the beginning (å $\rho \chi \eta \dot{\eta})$ of the Lord's ways in his works." The context shows that it is about Wisdom's participation in the creation of the world. In Legum Allegoriae 1,43, Philo of Alexandria states that God calls wisdom "the beginning ( $\left.\dot{a} \rho \chi \eta^{\prime}\right)$ and the image

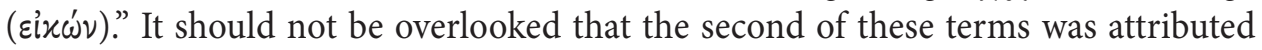
to Christ by the author of the hymn in the parallel verse initiating the first strophe (see above). Noteworthy, in Rev 3:14, the passage from the letter to the Church in Laodicea - a city next to Colossae - Christ is called "the beginning (åpy') of God's creation." This is a very important premise that established theological terminology was used in the communities of the Church in this region of Asia Minor. The term ápxý in Col 1:18b should be understood as the beginning, the first fruits, the cause of something and the principle. ${ }^{78}$

This meaning of ápxý is also suggested by the adjective $\pi \rho \omega \tau o ́ \tau o x o s$, which begins the second line of this strophe (identical to the first strophe). However, unlike

\footnotetext{
See Moo, The Letter, ad loc.

Cf. Moule, The Epistles, 69.

See also McConnell, "Colossians," 404.

Dunn, The Epistle, 97.
} 
in the first strophe, where Christ was called "the firstborn of all creation," here he is

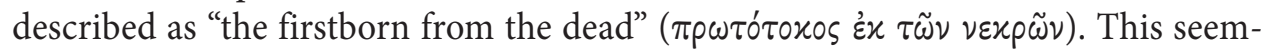
ingly enigmatic statement carries a very important theological message. ${ }^{79}$ In order to clarify its meaning, one should refer again to the Book of Revelation, where in 1:4-5 Christ is described as "He who is, and who was and who is to come..., the First-

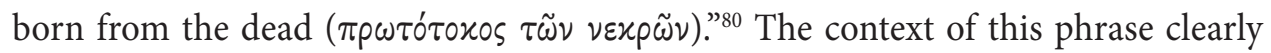
refers to the fact of Christ's resurrection. ${ }^{81}$ Here the reader should detect an echo of Paul's statement "Christ has been raised from the dead, the first fruits of those who have died" (1 Cor 15:20), ${ }^{82}$ indicating the temporal order of Christ's resurrection. But the meaning of the adjective $\pi \rho \omega \tau o ́ \tau o x o s$ governing the phrase $\varepsilon x \tau \tilde{\omega} \nu \nu \varepsilon x p \tilde{\omega} \nu$ in Col 1:18b is not limited to priority in the temporal aspect. According to the idea expressed in Rom 8:29, Paul sees Christ as "the Firstborn ( $\pi \rho \omega \tau$ tó brothers" and so as the first in God's family embracing those who believe in him. His resurrection is also to be theirs in the sense that with his resurrection began a new era in the history of salvation (the aforementioned, second stage in world history: see Rom 1:4). Christ's resurrection is, therefore, to be shared by all those who have died in him, by his whole family. Jesus' superiority in the family of believers is that of dignity, honour and authority - this idea will be developed and clarified in the immediate context.

The thought of Christ's primacy is continued in the following clause of purpose ${ }^{83}$

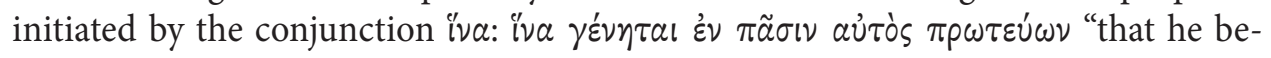
comes/is in everything first." ${ }^{84}$ Thus the author of the hymn explains that the purpose of Christ's resurrection from the dead was that he (emphatic aủ ós) "might become the first in everything" or, more literally, "so that he could become the first in everything." This interpretation is supported by the aorist form of the subjunctive $\gamma^{\varepsilon} v \eta \tau \alpha l$ "so that it may become" and the sense of the participle $\pi \rho \omega \tau \varepsilon \dot{\omega} \omega \nu$, which in Greek means not only primacy in the local and temporal sense, but also the primacy of dignity and power. As a result, the author of the hymn aims to convince the addressees that the purpose (and consequently the effect) of Christ's resurrection was for him to have absolute supremacy - pre-eminence over all mankind.

In the second stanza, it is clear that the author intratextually refers to the first

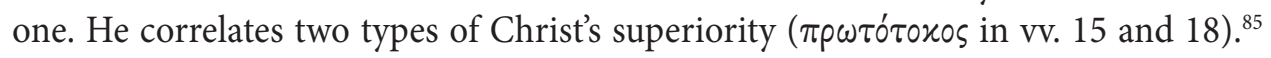

\footnotetext{
79 This issue is profoundly discussed by Charles H. Talbert (Ephesians, 190).

80 See Dunne, "The Regal Status of Christ," 16.

81 See also Bruce, The Epistles, 127.

82 See also 1 Cor 15:23; Acts 26:23.

83 Bartosz Adamczewski (List, 206) interprets this clause as an effect sentence, thus emphasizing the "justification of the title of Christ presented in 1:18b" in the interpretation.

84 McConnell ("Colossians," 404) argues that this expression shows that "Christ is described in Colossians in ways that would evoke images of the Roman emperor found in literature roughly contemporary with Colossians."

See also Heil, Colossians, 71.
} 
In the previous strophe, by presenting Christ as the Head of the body of the universe and comparing him to God's primordial Wisdom, he is presented as the Firstborn of all creation. In the second one, however, the situation of the universe and of humanity is radically changed - in a way complemented and improved. This reality is a consequence of Christ's resurrection as the Firstborn from the dead. Consequently, all believers in Christ become a new creation. ${ }^{86}$ At this point, we can find strong premises for the Pauline theology of Christ as the New Adam, who, through his passion, death

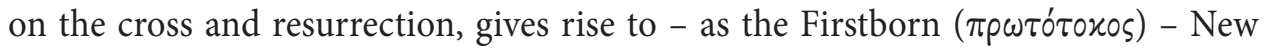
Man, through the redemption of the sin of the First Adam. ${ }^{87}$ In the Colossian hymn, the theology of Christ as the New Adam is linked with the theology of Christ as God's Wisdom, exposed in the first strophe, in a very skilful and creative way.

The entire verse 19 is an extension of the thoughts from v. 18b, which is clearly indicated by the subordinate conjunction ö $\tau$ ( (because) that begins this statement. This time it is about showing the results of the resurrection of Christ as the Firstborn from the dead. The opening conjunction ö $\tau$ l is followed by the expression $\dot{\varepsilon} \nu$ a $\tilde{\tau} \tau \tilde{\varphi}$ (in him), which occurs for the third time in Colossians 1:15-20 (previously in vv. 16 and 17). Placing $\dot{\varepsilon} v$ a $\tau \tilde{\omega}$ in the structure of the sentence immediately after the conjunction gives it an emphatic value (as already indicated), hence it takes the meaning "because it is in him (and in no one else)." This expression intratextually dialogues with its occurrences from the first strophe, showing the results of Christ's resurrection from the dead in the light of his participation in the creation and sustaining the world in existence, which was stated in the first stanza. While interpreting this passage, it should be kept in mind that the first strophe led the addressees to the idea of Christ as "the head of the body of the Church" (1:18a). Therefore, verse 19 pragmatically reveals the current ecclesiological perspective of the effects of the incarnation of the Son of God, the teaching and miraculous activities of Jesus as well as his passion, death on the cross and resurrection..$^{88}$

Due to the poetic nature of the hymn in Col 1:15-20, the unclear syntax of ö $\tau$ เ

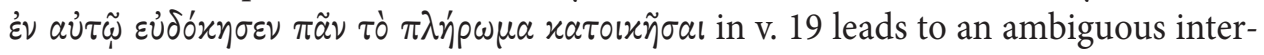

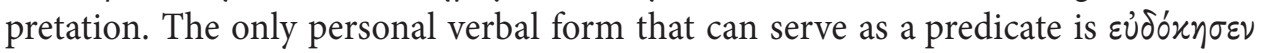
(pleased/willed; 3rd person singular). In turn, the only word that can act as a subject is the noun $\tau \dot{0} \pi \lambda \dot{\eta} \rho \omega \mu \alpha$. Hence, we would have the meaning "for in him all fullness pleased to dwell." ${ }^{99}$ Such a translation is grammatically correct, but syntactically contradictory to the continuation of this sentence in v. 20 , where the participle

\footnotetext{
86 This idea was already developed by Paul in 1 Cor 5:15-21, where it is, like in Col 1:15-20, closely related to the theology of reconciliation.

87 Cf. Moo, The Letter, ad loc.

88 James Dunn (The Epistle, 99) even claims that this part of the hymn is about presenting Christ in a similar way to the synoptic tradition. Stephen Wellum ("Jesus as Lord and Son," 36-40) rightly emphasizes a close relationship of the Christology of Jesus as the Son of God and the Lord in Col 1:15-20.

89 Such an interpretation is supported, for example, by MacDonald (Colossians, 63).
} 


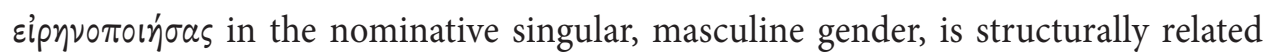
to the subject of v. 19. So, the clause in 1:19 demands a masculine, singular subject, which advocates the necessity to adopt an implicit subject resulting from the logic of the statement. The only person in the context who could act as an implied subject is

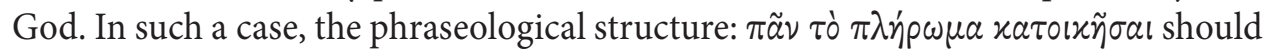
be interpreted in its entirety as a complement to the predicate (accusativus cum infinitivo). In such a case, the entire subordinate clause in 1:19 can be translated as "For in him [God] willed that all the fullness dwells" or "For God willed that all the fullness might dwell in him." Given the context of v. 20, which unfolds the idea present in v. 19 to show what God has accomplished in Christ (implicitly: because all the fullness dwelled in him), the second proposal should be accepted as the only correct one.

The neuter noun $\pi \lambda \eta \dot{\rho} \rho \mu \alpha$ (fullness) designating what dwells in Christ out of the will of $\operatorname{God}^{90}$ was a term frequently used in both Hellenism and Judaism of that period. ${ }^{91}$ In everyday Greek it was used, for example, to designate the entire crew of a ship. On the other hand, in religious and philosophical literature (e.g., Stoicism) it was used to describe all pervasive divine presence in the world..$^{92} \mathrm{~A}$ phraseology similar to that in Col 1:19 was applied for Zeus to say that he $\tau \dot{0} \pi \tilde{\alpha} \nu \pi \varepsilon \pi \lambda \eta^{\prime} \rho \omega \varkappa \varepsilon$ (fills everything [perfectum]). Also, one can find similar utterances in the writings of

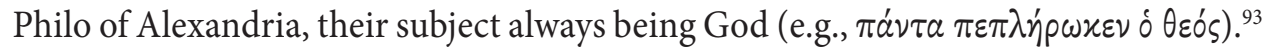
The idea of God's permeating presence is also very firmly rooted in biblical and extra-biblical Judaism, which can already be noted in Jer 23:24: $\tau \dot{\eta} \nu \gamma \tilde{\eta} \nu \dot{\varepsilon} \gamma \dot{\omega} \pi \lambda \eta \rho \tilde{\omega}$ $\lambda \varepsilon \gamma_{\varepsilon l}$ xúplos - "I fill the earth, said the Lord." In Wis 1:4 and other Jewish literature of the time, ${ }^{94}$ it is closely related to the idea of Wisdom or God dwelling (the verb

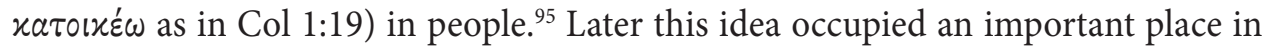
Gnostic (especially Valentinian) thought, where $\pi \lambda \eta \dot{\rho} \rho \omega \mu \alpha$ expressed the fullness of spiritual perfection emanating from God. ${ }^{96}$

Against this background, the meaning of Col 1:19 can be explained more specifically. The author makes the addressees aware that it was God's will (the verb

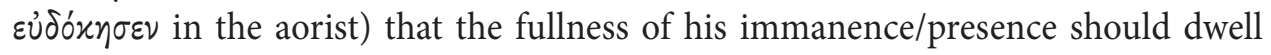
in Christ. ${ }^{97}$ He wants to convince them that Jesus Christ is the fullest expression of God - in him and through him God has revealed his being to man in the most

\footnotetext{
90 Cf. Bruce, The Epistles, ad loc.

91 See, too, Heil, Colossians, 72.

92 See, e.g., Seneca, De beneficiis 4,8,2.

93 See, e.g., Legum Allegoriae 3,4; De gigantibus 47; De Vita Mosis 2,238.

94 See e.g., The Testament of Zebulun 8,2; The Testament of Benjamin 6,4; 1 Enoch 49,3.

95 In Eph 3:14-17 it concerns the union of the believer with Christ.

96 These issues have comprehensively been presented in the monograph by Joseph Ernst, Pleroma, see esp. chapter four. In recent scholarship the authors focus on "how the term fits into the agenda of Col, namely, to present Christ as offering the full presence and power of God" - quotation from Gupta ("New Commentaries on Colossians," 13).

97 See Dunn, The Epistle, 101-102; Hughes, Philippians, ad loc.; Thurston, Reading Colossians, 25.
} 
perfect way. In his presence on earth - in words and deeds, and most fully in death and resurrection - God spoke to man most completely.

The last verse of the hymn (v. 20) is, structurally speaking, an extension of the idea expressed in a somewhat veiled poetic way in 1:18c and 1:19 (see above)..$^{98}$ From a syntactic point of view, the final lines of the hymn are structurally dependent on the conjunction iva, introducing a purpose clause in $18 \mathrm{c}$, and are an extension of the content announced in v. 19 by the explanatory conjunction ö $\tau$. The argument in v. 20 continues the thought of the primacy of Christ in all things (v. 18c), which was manifested by the indwelling of the fullness of the Godhead in him (v. 19). The content of v. 20 is structurally dependent on the predicate $\varepsilon \dot{0} \delta$ óx $\eta \sigma \varepsilon v$ from v. 19. In this final verse of the hymn, the author therefore explains that the priority of Christ is also due to the fact that it is God's will to "reconcile everything to himself through

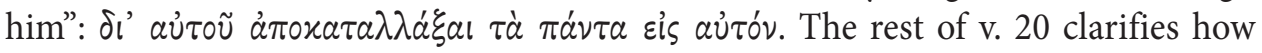
the work of reconciliation was accomplished. ${ }^{99}$ However, it should also be noted that in the structure of the hymn, verse 20 is a climax in relation to the thesis put forward in 1:14: in Christ "we have redemption, forgiveness of sins."100

The act of reconciling humankind to God ( $\varepsilon i \zeta$ aujtóv in 1:20) is expressed by

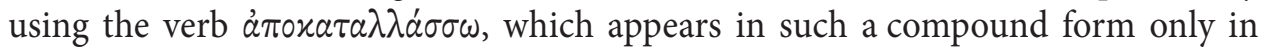
Col 1:20 and Eph 2:16 - apart from these texts we find it neither in Greek biblical literature nor in all the classical and Hellenistic Greek writings known to us. ${ }^{101}$ It can, therefore, be presumed that this term was coined by Paul or the Pauline school. What would be the purpose of adding the prefix $a \pi 0$ - to the verb $x a \tau \alpha \lambda \lambda \dot{\alpha} \sigma \sigma \omega$ already used by Paul in Romans and Second Corinthians to describe the reality of reconciliation of everything to God in the salvific work of Jesus Christ - namely in his passion, death and resurrection? The semantic function of the prefix $\alpha \pi 0$ - in Greek is generally to indicate that an action has been performed again. ${ }^{102}$ In our text (and in Eph 2:16), it is most likely about relating the reconciliation of humankind to God through Christ's passion, death and resurrection to the original state of the ideal God-man relationship (the state before the first fall, narrated in Gen 3). This relationship has been shaken by people many times despite God's reconciling initiatives (the history of salvation of the Old Testament). In this context, the prefix $a \pi 0$ - in the verb a $\pi 0 x a \tau a \lambda \lambda \alpha \dot{\sigma} \sigma \omega$ in Col 1:20 would emphasize the finality and irrevocability of the reconciliation of people with God in the saving work of Jesus Christ. ${ }^{103}$

The grammatical form of the verb $\dot{\alpha} \pi 0 x a \tau \alpha \lambda \lambda \alpha^{\prime} \xi \alpha l$ infinitivus aoristi activi clearly indicates a one-time activity performed in the past. It therefore refers not to

\footnotetext{
98 See also Garland, Colossians, 93.

99 Cf. Moo, The Letter, ad loc.

100 This is also noticed by Talbert (Ephesians, 190).

101 See Moule, The Epistles, 71.

102 See also Thurston, Reading Colossians, 26.

103 Cf. Liddell - Scott - Jones, A Greek-English Lexicon, 192.
} 
the whole of Christ's saving mission in the world, but to its special moment - to his passion, death and resurrection understood as components of one saving action of God.

Another important thing that results from the grammatical structure is the fact

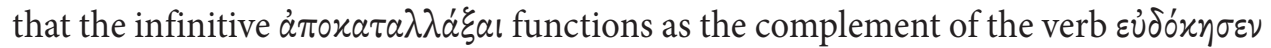
of 1:19, whose subject, as shown above, is God. Thus it is clear that the work of rec-

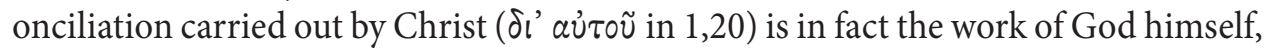

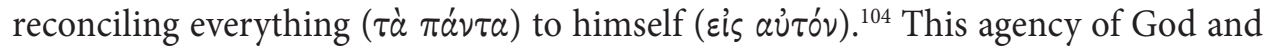
a kind of instrumentality of Christ in the work of reconciliation is a very important element of the biblical theology of reconciliation because the reconciliation made

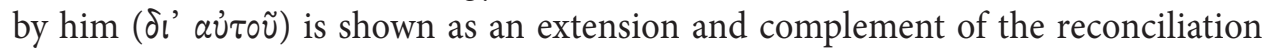
initiatives undertaken by God in the Old Testament. ${ }^{105}$

One should also pay attention to the possible ambiguity of the interpretation of the expression عis aũ óv in 1:20. ${ }^{106}$ In the previous paragraph, we referred it to God who reconciles everything to himself through Christ. But from a grammatical point of view, the phrase eis aưtóv can also be related to Christ and can mean for him. In

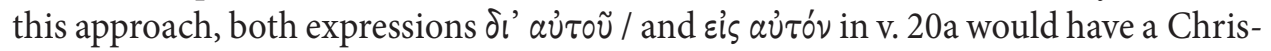
tological bearing - by him and for him, respectively, and would further emphasize the idea of the supremacy of Christ. ${ }^{107} \mathrm{~A}$ strong argument in favour of this direction of interpretation is the reference of both phrases to Christ in the preceding context

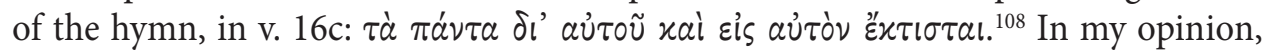
these two interpretations should not be opposed, but treated as complementary. This composition of the hymn can allow the reader to see its several complementary levels of interpretation as a proof of the author's poetic genius.

The beneficiary of the work of reconciliation accomplished in Christ is defined in Col 1:20 by the noun $\tau \dot{\alpha} \pi \dot{\alpha} \nu \tau \alpha$ (everything), repeated several times in the preceding context. In conclusion, in v. 20 the noun has the same meaning as in its previous occurrences: everything that exists, the entire created world in the broadest possible sense $^{109}$ - all spiritual and material entities existing in the entire universe created by God with the participation of Christ as the Firstborn of all creation. ${ }^{110}$ Adequately, the beneficiaries of the work of reconciliation accomplished by God in Christ are not only humans, but the entire created universe.

\footnotetext{
104 See Porter - Clarke, “Canonical-Critical Perspective”, 80.

105 On the most important premises of the theology of reconciliation in the OT, see Kręcidło, "Pojednanie w Starym Testamencie," 9-32.

106 See Metcalf, “The Atonement," 293.

107 This possibility was also seen by John H.P. Reumann (Taylor - Reumann, Colossians, 129).

108 This interpretation is supported by Adamczewski (List, 211), following Aletti (Colossiens 1,15-20, 30-32).

109 Similarly Bruce, The Epistles, ad loc. See also Porter - Clarke, "Canonical-Critical Perspective," 80.

110 See Heil, Colossians, 73.
} 


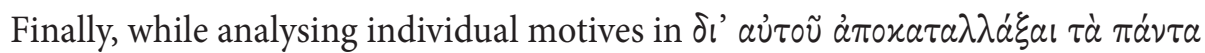

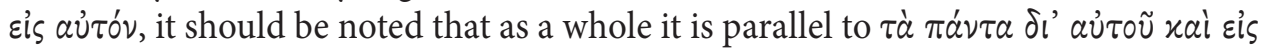

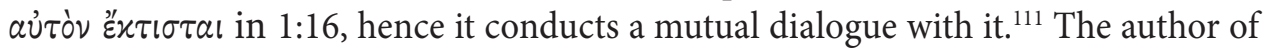
the hymn intentionally relates two realities: through him and for him God reconciled the world to himself. So, the work of reconciling the universe through the passion, death and resurrection of Christ is presented as the continuation and completion of the work of creation. The work of reconciliation is understood by the author as the creation of the world anew - a world in which those who remain in Christ are "new creatures." This idea plainly alludes to 2 Cor 5:17, where Paul affirms: "If anyone is in Christ, he is a new creation. The old has passed away, behold, the new has come."

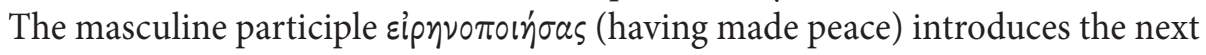

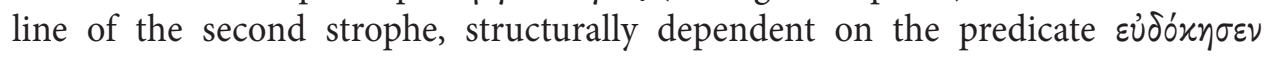
in 1:19. Thus, the subject of the act establishing peace is God. The whole phrase

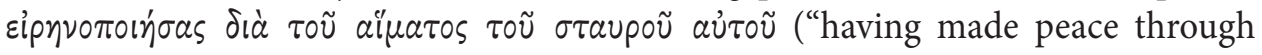
the blood of his cross") is structurally parallel to the previous one and clarifies its

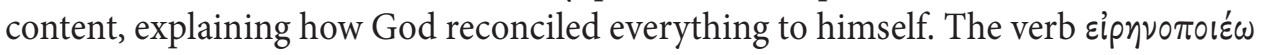
(to make peace) in Col 1:20 does not appear in any other passage in the New Testament, while in the Old Testament, it appears only in Prov 10:10 LXX. Yet, one finds

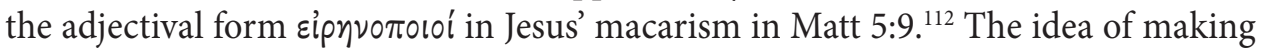
peace was quite popular both in the Old Testament and in the culture of the Mediterranean world of that time. In Col 1:20, it should be related to the Old Testament šălôm as a God-introduced state of peace, prosperity, fulfilment, etc. The term šălôm expresses one of the main strands of the Old Testament theology of reconciliation (see e.g., Num 6:26; Judg 6:24; Ps 29:11; 85:9; Isa 9:5-6; 45:7). ${ }^{113}$ In the Septu-

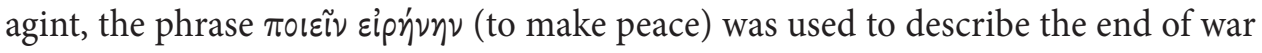
and the conclusion of a peace treaty between hitherto hostile parties (see e.g., Isa 27:5; 1 Macc 6:49.58; 11:51; 13:37). Looking at the pagan world of the ancient Mediterranean basin, we notice the idea of appeasing the angry deity by making an appropriate sacrifice to him or her. On the other hand, at the level of internal and external policies of various states, rulers "made peace" primarily by destroying their enemies. Peace was thus seen as the result of a war - a victory over the enemies.

It can be argued that it is this cultural awareness of the addressees that the author

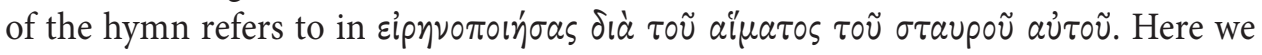
are dealing with a rhetorically clear juxtaposition between the idea of Christ, the triumphant Lord of the whole universe, ${ }^{114}$ developed especially in the first strophe, and the idea of bringing peace to the whole universe "through the blood of Christ's

111 Cf. Martin, Ephesians, 107.

112 See also Filo, De specialibus legibus 2,192.

113 See Moo, The Letter, ad loc.; Kręcidło, "Pojednanie w Starym Testamencie," 24-29.

114 This direction is evident in MacDonald, Colossians and Ephesians, 64. See also Scharlemann, "The Scope," 294-296. 
cross." ${ }^{115}$ God, therefore, did not reconcile the world to himself by making peace through the military destruction of his enemies, but through the blood of his Son shed on the cross. ${ }^{116}$ Reconciliation was achieved through Christ's passion, death on the cross and resurrection. ${ }^{117}$ This idea was already taken up in the proto-Pauline epistles in Rom 3:25 and 1 Cor 11:25 as well as in Eph 2:3-18. ${ }^{118}$

In the expression "through the blood of his cross" (1:20), one should not only perceive the elements of the expiatory sacrifice of Christ's life as a means of achieving the reconciliation of everything to God, but also the death on the cross as the most shameful punishment intended for bandits and captives, as well as a certain aspect of the scandal of the cross (see also 1 Cor 1:17-18, Gal 5:1;6:12 and Phil 2:8). The price of the reconciliation of everything to God was both Christ's physical suffering and his humiliation, deprivation of dignity, and an attempt to erase him from the collective memory of Jewish believers. The idea of achieving peace by fighting and eliminating enemies, so deeply rooted in the ancient culture, is contrasted with the idea of a onetime expiatory sacrifice of Christ, thanks to which the reconciliation of everything to God was achieved. ${ }^{119}$

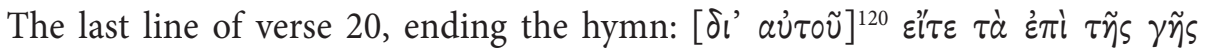

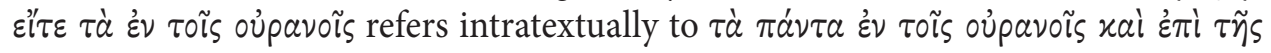
$\gamma \tilde{\eta} s$ in v. 16. Through this parallelism the reader is sensitized to the universal effects of the work of reconciliation accomplished in Christ's death on the cross. As in Christ all things were created (v. 16) - both in heaven and on earth - so "through the blood of his cross" everything on earth and in heaven was reconciled to God. ${ }^{121}$ It is thus evidently a question of juxtaposing the two most crucial stages in world history: the creation of everything and the work of reconciliation through Christ's blood of the cross. God's purpose in the work of reconciling the world in Christ was to restore to him the original harmony that the universe had after the creation and before the fall of the first people when evil crept into the world. Thanks to the work of Christ, the world was not only restored to its original state of perfection, but also the work of creation was completed - everything was born, i.e. created anew.

The final line of the second strophe should also be interpreted in the light of v. 18a: "He is the head of the body of the church." These correlated lines show the role

\footnotetext{
115 See Garland, Colossians, 94.

116 Heil, Colossians, 74. See also Metcalf, "The Atonement," 292-295.

117 Dunn, The Epistle, 103.

118 See Kręcidło, "Pojednanie podzielonej ludzkości," 199-220.

119 This issue is interpreted differently by Dunn (The Epistle, 103-104), who in the entire hymn of Col 1:15-20 primarily sees the language of triumph and war, and consistently argues that the "blood of the cross" is not the blood of expiatory sacrifice, but the blood of struggle.

120 This expression does not appear in some of the oldest manuscripts, therefore it can be treated as an ad-

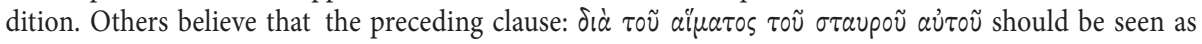
an addition as well. On the topic see in MacDonald, Colossians, 64-65.

121 So Bruce, The Epistles, ad loc.
} 
of the Church in the work of reconciling the whole world to God through Christ. This role can be seen in other passages of Colossians, connecting it with the activity of proclaiming the Gospel (implicitly: through the Church, e.g., 1:6.27) and living the Gospel (1:10). It is further explained and developed in the immediate context of 1:20 in verses 21-23. The universal reconciliation of the created world (people and all that exists in it) becomes possible thanks to the active mediation of the Church. ${ }^{122}$ A Christian community, whose members have accepted the gift of reconciliation, and now Christ's passion, death and resurrection are bearing abundant fruit in their lives, becomes an instrument in the process of reconciling all creation to God.

\section{Conclusions}

The exegetical analysis of the Christological hymn in Col 1:15-20 made possible to deduce a profound kerygmatic theology. The study of the first strophe (1:15-18a) highlighted the author's intention to show the function of Christ in creating the world and keeping it in existence, particularly by means of using metaphors from the Old Testament wisdom tradition and showing Christ as the New Adam. The poetic passage is also full of allusions to Hellenism and undoubtedly refers to the cosmological models of the universe conceived at that time. Using numerous metaphors, the author persuades the reader that Christ has an absolute primacy in the universe - he is the firstborn of all creation both in a chronological sense and in the sense of the priority of his authority and dignity. The first strophe ends by stating that Christ is the head of the body of the Church. At the same time, it presents a pragmatic idea leading to the argumentation of the second strophe of the hymn (1:18b-20). Referring to the primacy of Christ over all creation, the author focuses on the event of Christ's passion, death and resurrection as a key moment in the history of the universe. This salvific work of Christ, which is a phenomenon comparable only to the creation of the world, completes the work of creation. It is not only the restoration of the universe and of the relationship between God and man to the original state of harmony before the fall of the first people, but also, as it were, the creation of the world anew in Christ, in whom the whole fullness abides. The reconciliation of the world to God through Christ's blood shed on the cross completes the work of creation and presents man as a new creature in a qualitatively new relationship with God. The work of reconciliation has become a reality in the history of the world thanks to the testimony of the communities of the Church living the gift of reconciliation and proclaiming the Gospel.

122 Similarly Dunn, The Epistle, 104. See the extensive explanation in Peterson, "To Reconcile," 37-46. 


\section{JANUSZ KRĘCIDŁO}

\section{Bibliography}

Adamczewski, B., List do Filemona. List do Kolosan (Nowy Komentarz Biblijny. Nowy Testament 12; Częstochowa: Edycja Świętego Pawła 2006).

Aletti, J.-N., Colossiens 1,15-20. Genre et exégèse du texte. Fonction de la thématique sapientialle (Analecta Biblica 91; Rome: Biblical Institute Press 1981).

Aletti, J.-N., Saint Paul Épître aux Colossiens. Introduction, traduction et commentaire (Études Bibliques 20; Paris: Gabalda 1993).

Arnold, C.E., The Colossian Syncretism. The Interface between Christianity and Folk Belief at Colossae (Grand Rapids, MI: Baker 1996).

Balabanski, V., "The Holy Spirit and the Cosmic Christ: A Comparison of Their Roles in Colossians and Ephesians, or 'Where Has the Holy Spirit Gone?"' Colloquium 42/2 (2010) 173-187.

Balchin, J.F., "Colossians 1:15-20: An Early Christian Hymn? The Arguments from Style," Vox Evangelica 15 (1985) 65-94.

Bammel, E., "Versuch zu Col 1:15-20," Zeitschrift für neutestamentliche Wissenschaft 52 (1961) 88-95.

Barth, M. - Blanke, H., Colossians. A New Translation with Introduction and Commentary (The Anchor Yale Biblical Commentaries 34B; New Haven, CT - London: Yale University Press 2005).

Bauer, W. - Danker, F.W., A Greek-English Lexicon of the New Testament and Other Early Christian Literature (Chicago, IL: University of Chicago Press 2000) [BibleWorks 10].

Beale, G.K., "The Old Testament in Colossians: A Response to Paul Foster," Journal for the Study of the New Testament 41/2 (2018) 261-274.

Beale, G.K., Colossians and Philemon (Baker Exegetical Commentary on the New Testament; Grand Rapids, MI: Baker 2019).

Beetham, C.A., Echoes of Scripture in the Letter of Paul to the Colossians (Biblical Interpretation Series 96; Leiden: Brill 2008).

Behr, J., “Colossians 1:13-20: A Chiastic Reading," St Vladimir's Theological Quarterly 40/4 (1996) 247-264.

Bruce, F.F., “The 'Christ Hymn' of Colossians 1:15-20,” Bibliotheca Sacra 141 (1984) 99-111.

Bruce, F.F., The Epistles to the Colossians, to Philemon, and to the Ephesians (The New International Commentary on the New Testament; Grand Rapids, MI: Eardmans 1984).

Clark, B.T., Completing Christ's Afflictions. Christ, Paul, and the Reconciliation of All Things (Wissenschaftliche Untersuchungen zum Neuen Testament 2/383; Tübingen: Mohr Siebeck 2015).

Collins, C.J., "Colossians 1,17 'hold together': A Co-opted Term," Biblica 95/1 (2014) 64-87.

Dettwiler, A., "Démystification celeste: La fonction argumentative de l'hymne au Christ (Col 1,15-20) dans la lettre aux Colossiens," Les hymnes du Nouveau Testament et leurs fonctions. XXIIe congrès de l'Association catholique française pour l'étude de la Bible (Strasbourg, 2007) (eds. D. Gerber - P. Keith) (Lectio Divina 225; Paris: Cerf 2009) 325-340.

Dübbers, M., Christologie und Existenz im Kolosserbrief. Exegetische und semantische Untersuchungen zur Intention des Kolosserbriefes (Wissenschaftliche Untersuchungen zum Neuen Testament 2/191; Tübingen: Mohr Siebeck 2005). 
Dunne, J.A., “The Regal Status of Christ in the Colossian 'Christ-Hymn': A Re-evaluation of the Influence of Wisdom Traditions," Trinity Journal 32 (2011) 3-18.

Dunn, J.D.G., The Epistle to the Colossians and to Philemon (The New International Greek Testament Commentary; Grand Rapids, MI: Eerdmans 2014).

Ernst, J., Pleroma und Pleroma Christi. Geschichte und Deutung eines Begriffs der paulinischen Antilegomena (Biblische Untersuchungen 5; Regensburg: Pustet 1970).

Fee, G.D., "Old Testament Intertextuality in Colossians: Reflections on Pauline Christology and Gentile Inclusion in God's Story," History and Exegesis. New Testament Essays in Honor of Dr. E. Earle Ellis for his 80th Birthday (ed. Aang-Won Son) (London: Clark 2006) 201-221.

Feník, J. - Lapko, R., "The Reign of Christ in Colossians: A Reassessment," The Catholic Biblical Quarterly 81 (2019) 495-516.

Feuillet, A., Le Christ Sagesse de Dieu d’après les épîtres pauliniennes (Études Bibliques; Paris: Gabalda 1966).

Foster, P., "Echoes without Resonance: Critiquing Certain Aspects of Recent Scholarly Trends in the Study of the Jewish Scriptures in the New Testament," Journal for the Study of the New Testament 38/1 (2015) 96-111.

Foster, P., Colossians (London: Clark 2016).

Garland, D.E., Colossians and Philemon (The NIV Application Commentary; Grand Rapids, MI: Zondervan 1998).

Gnilka, J., Der Kolosserbrief (Herders theologischer Kommentar zum Neuen Testament 10/1; Freiburg: Herder 1980).

Gupta, N., "New Commentaries on Colossians: Survey of Approaches, Analysis of Trends, and the State of Research," Themelios 35/1 (2010) 7-14,

Heil, J.P., Colossians. Encouragement to Walk in All Wisdom as Holy Ones in Christ (Early Christianity and Its Literature 4; Atlanta: Society of Biblical Literature 2010).

Helyer, L.R., "Colossians 1:15-20: Pre-Pauline or Pauline?," Journal of the Evangelical Theological Society 26/2 (1983) 167-179.

Hughes, R.K., Philippians, Colossians, and Philemon. The Fellowship of the Gospel and the Supremacy of Christ (Wheaton, IL: Crossway 2013) [Kindle edition].

Ibrahim, N., Gesù Cristo Signore dell'universo. La dimensione cristologica della lettera ai Colossesi (Studium Biblicum Franciscanum Analecta 69; Jerusalem, IL: Franciscan Printing Press 2007).

Johnson, D.H., “The Image of God in Colossians,” Didaskalia 3/2 (1992) 9-15.

Käsemann, E., "A Primitive Christian Baptismal Liturgy," E. Käsemann, Essays on New Testament Themes (Studies in Biblical Theology 41; Naperville: Allenson 1964) 149-168.

Kehl, N., Der Christushymnus im Kolosserbrief (Stuttgart: Katholisches Bibelwerk 1967).

Kręcidło, J. "Pojednanie w Starym Testamencie,” Pozwólciepojednaćsięz Bogiem (ed. J. Kręcidło) (Studia Salettensia 1; Kraków: La Salette 2007) 9-32.

Kręcidło, J., "Pojednanie podzielonej ludzkości z Bogiem przez krzyżową śmierć Chrystusa. Rozwój chrystologicznej, soteriologicznej i eklezjologicznej argumentacji w Ef 2,11-22," Studia Nauk Teologicznych PAN 10 (2015) 199-220.

Langkammer, H., Wprowadzenie do Ksiag Nowego Testamentu (Wrocław: TUM 1990).

Liddell, H.G. - Scott, R. - Jones, H.S., A Greek-English Lexicon. With a Revised Supplement (Oxford: Clarendon 1996). 


\section{JANUSZ KRĘCIDŁO}

Lightfoot, J.B., Saint Paul's Epistles to the Colossians and to Philemon. A Revised Text with Introductions, Notes and Dissertations (Grand Rapids, MI: Zondervan 1976) [reprint of 1879 edition].

Lindemann, A., Der Kolosserbrief (Züricher Bibelkommentare zum Neuen Testament 10; Zürich: Theologischer Verlag 1983).

Lohmeyer, E., Die Briefe an die Philipper, an die Kolosser und an Philemon. Übersetzt und erklärt von Ernst Lohmeyer. Nach dem Handexemplar des Verfassers durchgesehene Ausgabe (Kritisch-exegetischer Kommentar über das Neue Testament 9; Göttingen: Vandenhoeck \& Ruprecht 1956).

Lohse, E., Colossians and Philemon (Hermeneia: A Critical and Historical Commentary on the Bible; Philadelphia, PA: Fortress 1988).

Louw, J.P. - Nida, E.A., Greek-English Lexicon of the New Testament Based on Semantic Domains (New York: United Bible Societies 1988-1989) I-II [BibleWorks 10].

Macaskill, G., "Union(s) with Christ: Colossians 1:15-20," Ex Auditu 33 (2017) 92-207.

MacDonald, M.Y., Colossians and Ephesians (Sacra Pagina 17; Collegeville, MI: Liturgical Press 2008).

Maisch, I., Der Brief an die Gemeinde in Kolossä (Theologischer Kommentar zum Neuen Testament 12; Stuttgart: Kohlhammer 2003).

Martin, D.B., The Corinthian Body (New Haven, CT: Yale University Press 1999).

Martin, E.D., Colossians, Philemon (Believers Church Bible Commentary; Scottdale, PA: Herald Press 1993).

Martin, R.P., Ephesians, Colossians, and Philemon (Atlanta, GA: John Knox Press 1991).

McConnell, J.R., "Colossians: Background and Contexts," Review and Expositor 116/4 (2019) 397-410.

McKnight, S., "Introduction," The Letter to the Colossians (New International Commentary on the New Testament; Grand Rapids, MI: Eerdmans 2018) (Kindle edition).

Medley, M.S., "Subversive Song: Imagining Colossians 1:15-20 as a Social Protest Hymn in the Context of Roman Empire," Review and Expositor 116/4 (2019) 421-435.

Metcalf, R., "The Atonement in the Letter to the Colossians," Journal of Theological Interpretation 13/2 (2019) 280-302.

Moo, D.J., The Letter to the Colossians, and to Philemon (The Pillar New Testament Commentary; Grand Rapids, MI: Eerdmans 2008) (Kindle edition).

Moule, C.F.D., The Epistles to the Colossians and to Philemon (The Cambridge Greek Testament Commentary; Cambridge University Press 1957).

Northcott, C.S., "King of Kings' in Other Words: Colossians 1:15a as a Designation of Authority Rather than Revelation," Tyndale Bulletin 69/2 (2018) 205-224.

Peterson, R.A., “'To Reconcile to Himself All Things’: Colossians 1:20,” Presbyterion 36/1 (2010) 37-46.

Porter, S.E. - Clarke, K.D., "Canonical-Critical Perspective and the Relationship of Colossians and Ephesians," Biblica 78/1 (1997) 57-86.

Scharlemann, M.H., “The Scope of Redemptive Task (Colossians 1:15-20)," Concordia Theological Monthly 36/5 (1965) 291-300.

Schweizer, E., "Colossians 1:15-20," Review and Expositor 87/1 (1990) 97-104. 
Standhartinger, A., Studien zur Entstehungsgeschichte und Intention des Kolosserbriefes (Supplements to Novum Testamentum 94; Leiden: Brill 1999).

Sumney, J.L., "Writing 'in the Image' of Scripture: The Form and Function of References to Scripture in Colossians," Paul and Scripture. Extending the Conversation (ed. C.D. Stanley) (SBL Early Christianity and Its Literature 9; Atlanta, GA: Society of Biblical Literature 2012) 185-229.

Talbert, C.H., Ephesians and Colossians (Paideia: Commentaries on the New Testament; Grand Rapids, MI: Baker Academics 2007).

Taylor, W.F. - Reumann, J.H.P., Ephesians, Colossians (Augsburg Commentary on the New Testament; Minneapolis, MN: Augsburg 1985).

Thurston, B., Reading Colossians, Ephesians, and 2 Thessalonians. A Literary and Theological Commentary (Reading the New Testament; New York: Smyth \& Helwys Publishing 1995).

Tracy, S.R., Living under Lordship of Christ. The Ground and Shape of Paraenesis in the Epistle to the Colossians (Diss. University of Sheffield; Sheffield 1995).

Trainor, M., "The Cosmic Christology of Colossians 1:15-20 in the Light of Contemporary Ecological Issues," Australian Biblical Review 53 (2005) 54-69.

Wellum, S.J., "Jesus as Lord and Son: Two Complementary Truths of Biblical Christology," Criswell Theological Review 13/1 (2015) 23-45.

White, J., Der Brief des Paulus an die Kolosser (Historisch Theologische Auslegung; Witten: SCM R. Brockhaus 2018).

Wright, A.M., "Disarming the Rulers and Authorities: Reading Colossians in Its Roman Imperial Context," Review and Expositor 116/4 (2019) 446-457. 
